\section{Immunologi for viderekomne}

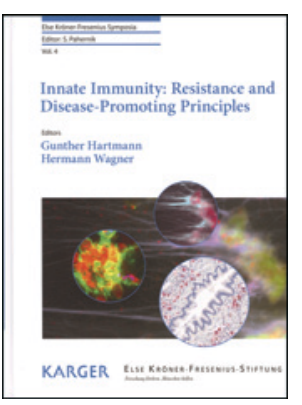

Gunther Hartmann, Hermann Wagner, red. Innate immunity: resistance and disease-promoting principles

130 s, ill. Basel: Karger, 2013. Pris CHF 79 ISBN 978-3-318-02347-3

Det medfødte immunsystemet består av evolusjonsmessig godt bevarte forsvarsmekanismer som er spesielt viktige i forstelinjeforsvaret mot mikrober. I 1970- og 1980-årene kom det frem at den sentrale bakterielle celleveggskomponenten lipopolysakkarid (LPS) hos gramnegative bakterier induserte meget kraftige immunologiske responser via mekanismer i det medfødte immunsystemet - med potensial for blant annet septisk sjokk og disseminert intravaskulær koagulasjon (DIC) ved meningokokksepsis. Hvilke reseptorer på celleveggen lipopolysakkarid stimulerte, og hvilke intracellulære og ekstracellulære responser som ble initiert, var imidlertid lenge et ukjent kapittel.

I slutten av 1990-årene ble lipopolysakkaridreseptoren, toll-liknende reseptor 4 (TLR4), første gang beskrevet. Denne oppdagelsen førte til betydelig økt interesse for og et enormt forskningssøkelys rettet mot det medfødte immunsystemet. Etter hvert oppdaget man at det ikke bare var eksogene mikrober som kunne initiere kraftige immunologiske responser via slike reseptorsystemer. Det ble avdekket at endogene molekyler, som bl.a. ekstracellulært forekommende DNA, «heat-shock»-proteiner (HSP) og urinsyre, også er potente betennelsesstimulatorer. I tillegg vet man nå at betennelsesreaksjoner med involvering av det medfødte immunsystemet er av sentral betydning ved en rekke kroniske sykdommer som bl.a. aterosklerose, adipositas og diabetes mellitus. Begrepet autoinflammatoriske sykdommer har derfor fått ny og utvidet betydning.

Det er vanskelig å ha god oversikt over dette forskningsfeltet grunnet den raskt økende tilgangen på forskningsdata og det interdisiplinære og translasjonsmessige preget. Denne boken er en samling av innlegg holdt ved et symposium våren 2012 - Else KrønerFresenius symposium - med hensikt å presentere oppdatert kunnskap om ulike aspekter i det medfødte immunsystemet.

Kapitlene spenner fra betennelsesmekanismer ved kolorektal kreft, organskade ved reperfusjon, diabetes mellitus og Alzheimers sykdom til tarmfloraens påvirkning av en del sentrale immunologiske forhold. Boken presenterer oppdatert kunnskap, men er tematisk springende. Artiklene er forfattet av anerkjente forskere, men innholdet bærer et klart preg av deres subjektive forskningsinteresse med åpenbart behov for å markere betydningen av egen forskning. Kvaliteten er derfor ujevn, men noen artikler er meget gode. Spesielt kapitlene om øyecellebetennelse og diabetes mellitus type 2, av Marc Donath, og lymfoide celler i hud og slimhinner, av Laurel Monticelli og David Artis, er spennende å lese, ikke bare fordi de er velformulerte og gir en god oversikt, men også fordi artiklene ikke har et for subjektivt preg.

Uansett er dette er en bok som krever mye immunologisk forkunnskap, og den appellerer først og fremst til forskere eller klinikere med spesiell kompetanse og særinteresse for det medfødte immunforsvar.

\section{Grundig om stamceller og stamcelleforskning}

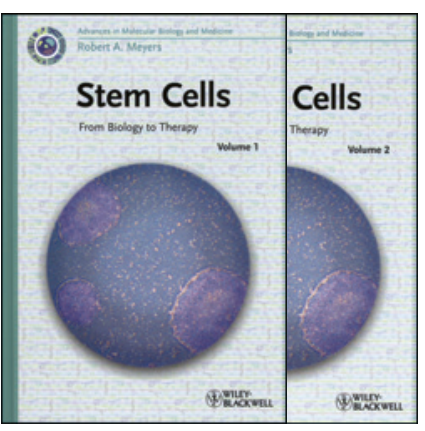

Robert A. Meyers, red.

Stem cells

From biology to therapy. 2 bd.

778 s, tab, ill. Chichester:

Wiley-Blackwell, 2013

Pris GBP 205

ISBN 978-3-527-32925-0

Denne utgivelsen består av to bind og er av meget høy kvalitet.

Bøkene er skrevet av fremstående eksperter på området, blant annet fem nobelprisvinnere.

Verket består av til sammen 26 kapitler og er delt inn i fire hoveddeler: basal biologi, laboratoriemetoder, stamcelleterapi og stamceller og sykdom.

De 26 kapitlene er skrevet av forskjellige forfattere, og hvert kapittel har egne referanser. Hvert kapittel kan leses som en selvstendig oversiktsartikkel. Redaktøren har gjort en god jobb med å begrense overlapping mellom de forskjellige kapitlene, samtidig som hele temaet stamceller fremstår som godt dekket.

Bøkene er som nevnt delt inn i fire hoveddeler, og jeg vil anta at det er delene om stamcelleterapi og stamceller og sykdom som vil interessere flest leger. Delen om stamcelleterapi inneholder blant annet spennende kapitler om stamcelleforskning ved Parkinsons sykdom, hemoglobinopatier og ryggmargsskader. I disse kapitlene forklarer forfatterne hvorfor stamcellebehandling kan ha potensial for store medisinske gjennombrudd ved disse diagnosene, samtidig som de klargjør hvilke vanskeligheter som gjenstår før stamcelleterapi kan bli mer enn eksperimentell behandling ved disse diagnosene.

I delen om stamceller og sykdom konsentrerer forfatterne seg om vår viten om kreftstamceller. Denne delen kan være nyttig for mange som ønsker å få en dypere forståelse for behandlingen av metastasert kreftsykdom, og hvorfor cellegift ikke alltid er effektivt.

Det er relativt få figurer og tabeller, men illustrasjonene som er tatt med, er oversiktlige og klargjørende.

Jeg kan anbefale bøkene for avdelinger og enkeltpersoner som ønsker et oppslagsverk, eller som ønsker å sette seg grundig inn i temaet stamceller og få et overblikk over den omfattende forskningen som er gjort på stamceller. Jeg vil ikke anbefale dem til personer som ønsker å få et innblikk i dette store temaet. Til det er detaljrikdommen for stor, og teksten er primært skrevet med tanke på personer som allerede har kjennskap til temaet. Det kan også innvendes at det kan være vanskelig å se de store linjene innen temaet stamcelleforskning første gang man leser. Prisen på over 2000 kroner er relativt høy, men som et oppdatert oppslagsverk over temaet stamceller vil jeg hevde at de to bindene kan betraktes som en gullstandard.

Knut Liseth

Avdeling for immunologi og transfusjonsmedisin

Haukeland universitetssykehus 